\title{
Fish Nutritional Value as an Approach to Children's Nutrition
}

\author{
Sahya Maulu ${ }^{1}$, Kundananji Nawanzi ${ }^{2}$, Mohsen Abdel-Tawwab ${ }^{3}$ and Hala Saber Khalil ${ }^{4,5,6 *}$ \\ ${ }^{1}$ Centre for Innovative Approach Zambia (CIAZ), Lusaka, Zambia, ${ }^{2}$ Department of Agriculture and Aquatic Sciences, Kapasa \\ Makasa University, Chinsali, Zambia, ${ }^{3}$ Department of Fish Biology and Ecology, Central Laboratory for Aquaculture Research, \\ Agriculture Research Center, Abbassa, Sharqia, Egypt, ${ }^{4}$ Aquaculture and Fisheries Group, Wageningen Institute of Animal \\ Sciences, Wageningen University and Research, Wageningen, Netherlands, ${ }^{5}$ WorldFish, Africa Aquaculture Research and \\ Training Center, Abbassa, Egypt, ${ }^{6}$ Aquaculture Division, National Institute of Oceanography and Fisheries (NIOF), Cairo, Egypt
}

Fish is a relatively cheap and accessible source of animal protein for human consumption even in rural communities. It is critical for global food and nutrition security, and its consumption continues to increase. As a highly nutritious food, fish consumption is highly recommended for children and expectant mothers for normal growth and development. The present paper explores the nutritional value of fish as approach to nutrition in children and its benefits. The findings reveal that fish is a valuable source of essential amino acids (EAA) and polyunsaturated fatty acids (PUFAs) that play important physiological functions for maintenance and development of fetuses, neonates, and infant brains. Therefore, it could be a valuable tool in the fight against food insecurity and malnutrition. However, fish and fish products are also highly susceptible to contamination by various organic and inorganic compounds that threaten public health. Particularly, heavy metals and biogenic amines (BAs) have shown adverse effects when contaminated fish is consumed, and the effects in children have been worse. Hence, while fish consumption is highly recommended for children's nutrition, the safety and quality of the product should always be checked to safeguard public health.

Keywords: aquatic food, omega-3, nutrition, malnutrition, brain development, PUFAs, physiological functions

\section{INTRODUCTION}

Fish is consistently among the most commonly used and low-cost dietary sources of animal protein for most people worldwide $(1,2)$. It is a valuable source of essential nutrients, especially highquality protein and fats (macronutrients), vitamins, and minerals (micronutrients) that make a vital contribution to the world's food and nutrition security (3). As a food product, fish is of greater importance in developing countries where it accounts for $75 \%$ of the daily animal protein, referred to as "rich and poor food" as an important companion $(4,5)$. Compared with other animal protein sources, fish is readily available even in poorer communities at a relatively cheaper price. Furthermore, fish production through aquaculture is considered sustainable and the most efficient way to produce high quality proteins for human consumption (6-8).

In children, inadequate intake of dietary protein could lead to serious health consequences, including stunted growth and poor development (9). Hence, the protein component of the human diet is very crucial and an important area of focus when it comes to malnutrition due to its physiological functions (9). Globally, malnutrition remains a major problem and it is estimated that 47 million children suffer from stunting, due to the lack of micronutrients of vitamin A, iron, and iodine, which is a source of public health concern in the world (10). Its consequences include nutritional blindness, impaired learning capabilities, poor growth, and increased morbidity 
and mortality rates (4). In many developing countries, malnutrition is a major risk for sickness and death in children (11). This is mainly driven by lack of access to high quality food products. Fisheries and aquaculture programs can address and mitigate issues of malnutrition in the world by increasing the access to fish $(12,13)$ due to its nutritional value. Therefore, increasing fish production could increase the access to fish products and improve the nutritional status in children which has the potential to end malnutrition and food insecurity.

Recently, the number of studies exploring the importance of fish consumption in children have increased. This is because fish has been recognized as an important source of high quality animal protein required for bodybuilding and other physiological functions in children compared to adults (14). Besides, during childhood stage, the provision of adequate protein intake is very crucial for the overall growth and development into adulthood. As fish is tender and easily digested than meat, its consumption in children would be an excellent source of calcium and fluorine essential for the development of strong bones and teeth (15). Furthermore, the consumption of fish, particularly oily fish, is essential for optimal development of the brain and neural system of the children, as omega-3 fatty acids in the form of docosahexaenoic (DHA) rather than alpha-linoleic acid (ALA) are required for optimal brain development (16). Unfortunately, much of the existing studies on fish have had a bias toward its economic importance and merely as a food item, while paying less attention to its nutritional value, particularly in children nutrition. Understanding the benefits associated with fish consumption is very cardinal for promoting the consumption of fish as it is often the cheapest source of animal protein in marginalized communities to improve the nutritional status normal development in children. This study, therefore, aimed to synthesize existing studies on the nutritional value of fish, including the benefits and risks associated with its consumption in children.

\section{GLOBAL OVERVIEW OF FISH CONSUMPTION}

Fish is very crucial to a nutritious diet in many areas across the world and it provides about 3.3 billion people with almost $20 \%$ of their average per capita intake of animal protein. As the global population increases, potential nutritional concerns are raised, and fish represents an important source of animal protein. For this reason, global fish for human consumption is projected to increase by $16.3 \%$ indicating that $90 \%$ of the fish being produced will be utilized for human consumption by the year 2029 (17). In 2018, fish accounted for about 17\% of the total animal protein and $7 \%$ of this was animal protein consumed globally (3). The consumption of fish and the fish products has experienced major changes in the past decades. The world evident per capita fish consumption has been increasing steadily from an average of $12.5 \mathrm{~kg}$ in the 80 's to $14.4 \mathrm{~kg}$ in the 90 's and reaching $20.5 \mathrm{~kg}$ in 2017 (18). This expansion in the consumption have been driven not only by the increase in production but also by the nutritional standards it has shown to provide to the people, reduced waste, better utilization, improved distribution channels, and increased demand (3). Therefore, the increase in the consumption globally is an indication that the health benefits of fish consumption are manifold and well-understood from both scientific and nutritional perspectives. This also means that fisheries and aquaculture will continue to play a very crucial role in meeting the animal protein demands of the global population, with aquaculture being the dominant supplier (Figure 1).

\section{The Chemical Composition of Fish}

Fish contains $18-20 \%$ protein, and contains eight essential amino acids including sulfur containing lysine, methionine, and cysteine (12). It provides easily digestible protein of high biological value that is important for the growth and development of the body, the maintenance and repair of worn out tissues and for the production of enzymes and hormones necessary for many of the body's processes, it's contains less fat than red meat (19).

The fat content ranges from 0.2 to $25 \%$, especially polyunsaturated fatty acids (PUFAs), which are essential for the proper growth of children and are not associated with the occurrence of cardiovascular disease (20). Fats also contribute to the energy supply and aid in the adequate absorption of vitamins $\mathrm{K}, \mathrm{D}, \mathrm{A}$, and $\mathrm{E}$ (21). Fish is a vital source of vitamins Figure 2, especially vitamins $\mathrm{A}$ and $\mathrm{D}$ of the fats, as well as thiamine, riboflavin, and niacin (vitamins B1, B2, and B3) (22). Vitamin A found in fish is more available in the body compared to plant foods and is essential for normal vision and bone growth, also, fatty fish contains more vitamin A than the lean types (22). Vitamin D, found in fish liver and oils, is essential for bone growth because, it is essential for calcium absorption and metabolism (23). Energy metabolism requires thiamin, niacin, and riboflavin (23). Fresh fish provides a small amount of vitamin $\mathrm{C}$, which is essential for wound healing, maintaining the integrity of tissue, and assisting in the absorption of iron in the nervous system (22).

Phosphorus, calcium, iodine, iron, selenium, fluorine, and zinc are among the minerals found in fish and are extremely "bioavailable," ensuring that they are readily consumed by the organism (24). Iron is critical for the formation of hemoglobin in the blood, which would be responsible for distributing oxygen across the body (24). Calcium is critical for the development and mineralization of bones, as well as the normal operation of tissues and the central nervous. It also plays a significant role in the clotting of blood (25). When young fish are consumed with their bones, the phosphorus, calcium, and fluorine consumption is greatest (25). Zinc is needed for growth performance, function of immune system and the maintenance of healthy skin (26). Iodine, found in aquatic food, is necessary for hormones that control body metabolism, growth and proper behavioral development in children (22). Fish clearly provides more to people's diets than just high-quality protein (27). As a result, fish can be a staple to every diet, avoiding starvation which, make these nutrients readily accessible to absorption by organs.

In recent decades, as people's concerns about their health have grown, so has their concern about fats (28). Fatty acids are molecules consisting of one glycerol and three fatty acids that serve as a source of energy in our body and are deposited in the 


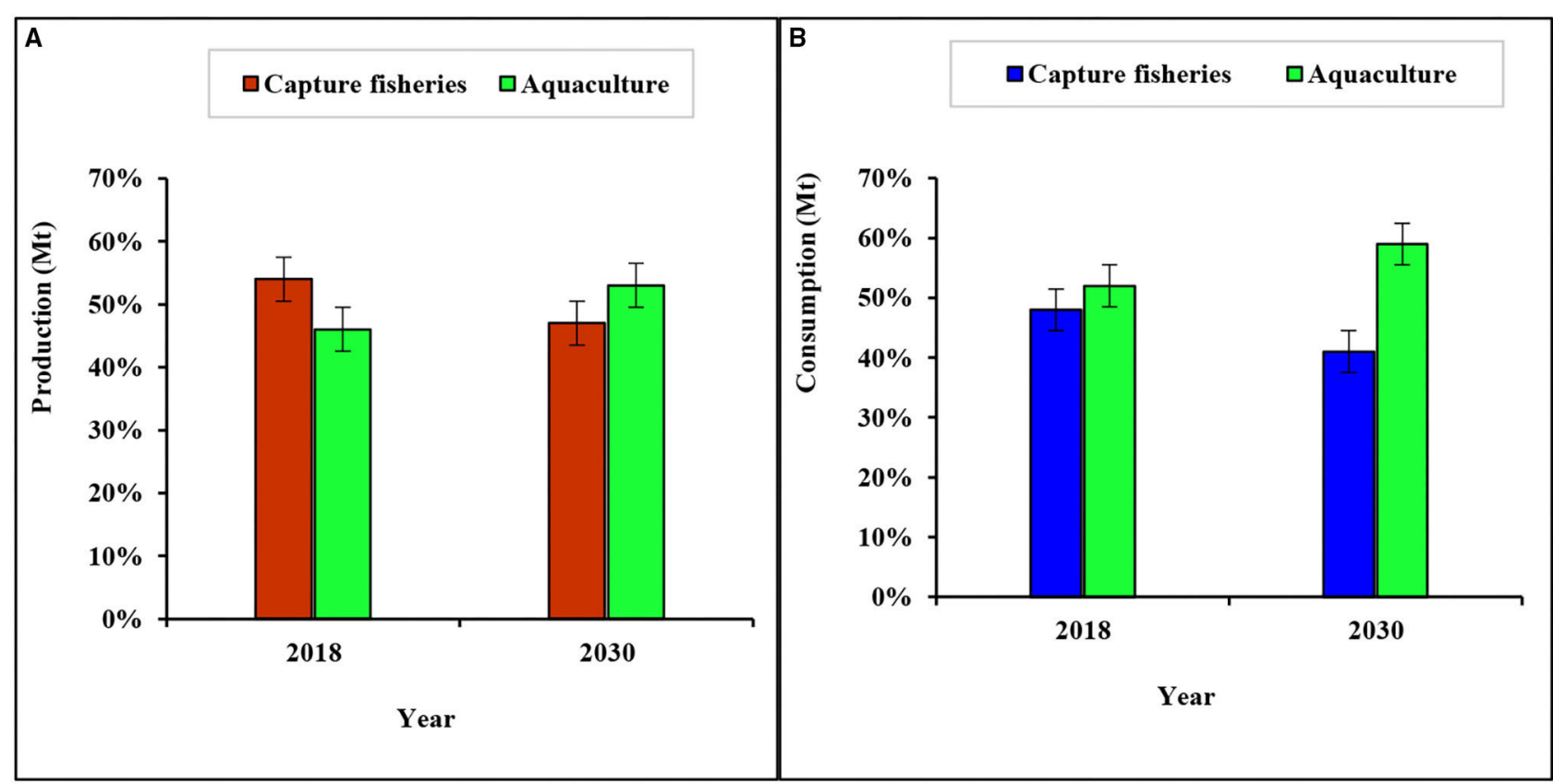

FIGURE 1 | Global fish (A) production in 2018 and projected production in 2030, and (B) consumption in 2018 and projected consumption in 2030 , from capture fisheries and aquaculture. Source: Adapted from FAO (3).

meat, muscles and liver (29). When fat is ingested, lipase breaks it down into one glycerol and three fatty acids, while a few fatty oils molecules are pass through intact through the intestine (30). The ingested fat is at initial storage in the liver, the muscular or subcutaneous inner layer and then broken down as needed to provide energy (31).

Furthermore, saturated and unsaturated fatty acids are distinguished by the presence or absence of an intramolecular double bond $(20,32)$. Saturated fatty acids are found in animal oils and are harmful to an individual's health, while unsaturated fatty acids are found in vegetable oils and are beneficial to an individual's health $(21,33)$. As a result, polyunsaturated fatty acids (PUFAs), such as omega-3s, have received significant attention (12). There are several medications and able to pay foods on the market, and the number of products aimed at children has risen as well (34). However, since there is concern about indiscriminate and excessive PUFA intake, it is critical to understand the correct use of PUFAs (35). As a result, the purpose of this study is to investigate at the fundamental concepts, kinds of PUFAs, physiological mechanisms of action of PUFAs, and PUFA consumption in children.

\section{Polyunsaturated Fatty Acid Types}

Animal oils, like pork, and butter, are rich in saturated fatty acids. Fish oil is an unsaturated fatty acid similar to animal oil (36). Unsaturated fatty acids make up the majority of vegetable fats, although saturated fatty acids like those found in coconut and palm oils are also present (37).

The persistent stability of saturated fatty acids causes them to harden and become white at cold temperatures. It is easy to store and does not easily strip when exposed to heat or pressure (38).
Saturated fatty acids are problematic because they contribute to a number of circulatory and vascular issues (39). Saturated fatty acids, that harden at low temperatures, can cause atherosclerosis, angina, and stroke by raising cholesterol levels, and they can also alter blood flow (40). Some saturated fatty acid such as myristic acid C14/0, stearic acid C18/0, monounsaturated fatty acid as palmitoleic acid C16/1, Oleic acid C18/1 (41).

Unsaturated fatty acids on the other hand do not solidify and exist in liquid form at low temperatures due to their structural instability; they strip quickly when heat or pressure is applied, and spoil quickly (42). Unsaturated fatty acids are recognized to offer a variety of health benefits (43). Unsaturated fatty acidslinolenic acid (ALA) C18/3, linoleic acid C18/2, arachidonic acid (AA) C20/4; n-6, eicosapentaenoic acid (EPA) C20/5; n-3, and docosahexaenoic acid (DHA) C22/6; $n-3$ are those that have a physiologically vital role for children (44). The location of the first omega double bond, the carbon atom at the end of the carbon chain (the $\mathrm{CH} 3$ radical) within the fatty acid molecular structure, is used to classify unsaturated fatty acids (45). The essential fatty acids ALA, linoleic acid, and AA are required for optimal growth and health, but are not produced in animals' bodies, so they are classified as essential fatty acids (46). Wild fishes have higher levels of omega-3 PUFAs than farmed fish (47). Cold-water fishes contents contain greater amounts of long chain n3 PUFAs, which aid in their adaptation to the cold temperature (47). Aquatic oil, can provide EPA, Docosapentaenoic acid (DPA), DHA, and arachidonic acid (ARA), that can be used immediately in the body for regular physiological processes $(20,48)$. Omega-chain fatty acids are also known as unsaturated fatty acids (49).

Omega-3 (n-3), omega-6 (n-6), and omega-9 are all good examples (n-9) (50). Fish oil (for example, Sardine (10.14 EPA; 


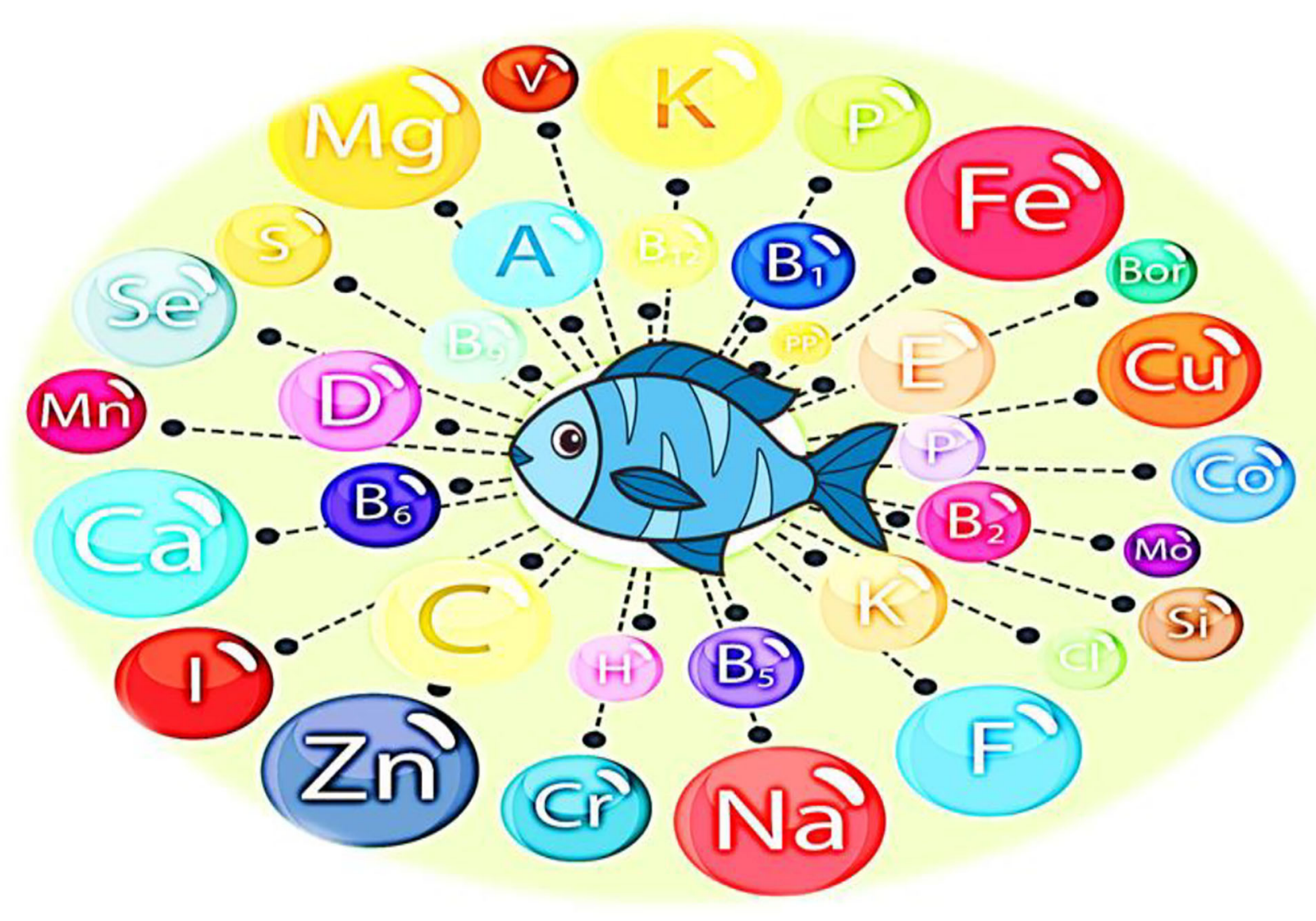

FIGURE 2 | Fish as a vital source of vitamins and minerals for children.

10.66 DHA), Menhaden (13.17 EPA; 8.56 DHA), Salmon (13.20 EPA; 18.23 DHA), Cod liver (9.90 EPA; 10.97 DHA), Herring (6.27 EPA; 4.21 DHA) and Fish such as Caviar, black and red (2.74 EPA; 3.80 DHA), values are g/100 g. (51). Vegetable oils (such as perilla oil, flaxseed oil, soybean oil, and canola oil) are both high in Omega-3. ALA, EPA and DHA are the nutritionally necessary omega-3 fatty acids $(52,53)$.

Animals have a limited ability to synthesize EPA and DHA (long-chain fatty acids) from ALA because they cannot produce omega-3 fatty acids (short-chain fatty acids) $(54,55)$. Grape seed oil, soybean oil, corn oil, sunflower oil, and cottonseed oil are high in omega- 6 fatty acids $(56,57)$. Linoleic acid, linoleic acid, and AA are all omega- 6 fatty acids (58). Oleic acids belong to the class of omega- 9 fatty acids, and make up more than $80 \%$ of olive oil (59). Lard, palm oil, and sesame oil also contain omega-9 fatty acids (60).

\section{PUFAs' Physiological Mode of Action}

PUFAs are necessary fatty acids that are not produced in animals' bodies but are required for optimal growth and health (61, 62). When PUFAs are deficient, a variety of symptoms can develop, therefore PUFAs are regarded medically essential (63). The positive health activities of DHA and EPA, which are the materials designated as omega-3 functionality, are particularly well-established $(47,55)$. EPA improves blood circulation and lowers cholesterol levels in the blood (low-density lipoprotein, LDL) $(64,65)$. DHA is a fatty acid present in brain tissue and the optic nerve, which assists to rejuvenate brain cells and improve brain function, Figure 3 (66-68). Omega-3 fatty acids, on the other hand, have anti-thrombotic, anti-arrhythmic, and antiinflammatory properties, whereas omega- 6 fatty acids are known to promote inflammation and thrombus development (69). DHA has been the most common n-3 LC-PUFA in the human nervous system (NS) (5 $\mathrm{g}$ in the human brain, 15\% total fatty acids (FAs) (70). Additionally, DHA phospholipids have a great level of functional flexibility, which may be a key feature of a range of biochemical characteristics, including cognitive activities, acyl chain order, phase behavior, and synapse transmission locations of the synaptosomal cytoplasmic membrane in the brain has been preserved throughout growth and maintenance $G$ proteincoupled signaling which leads to altered gene expression (71, 72). DHA also serves as an extra-and intracellular transcription factor, and blood DHA levels have been related to improved neurological development and visual in children $(70,73)$. EPA can stimulate the regeneration process of remyelination and cure multiple sclerosis of the central nervous system (CNS), after toxic damage to CNS oligodendrocytes (74). PUFAs' supplementation can help children with attention problems 


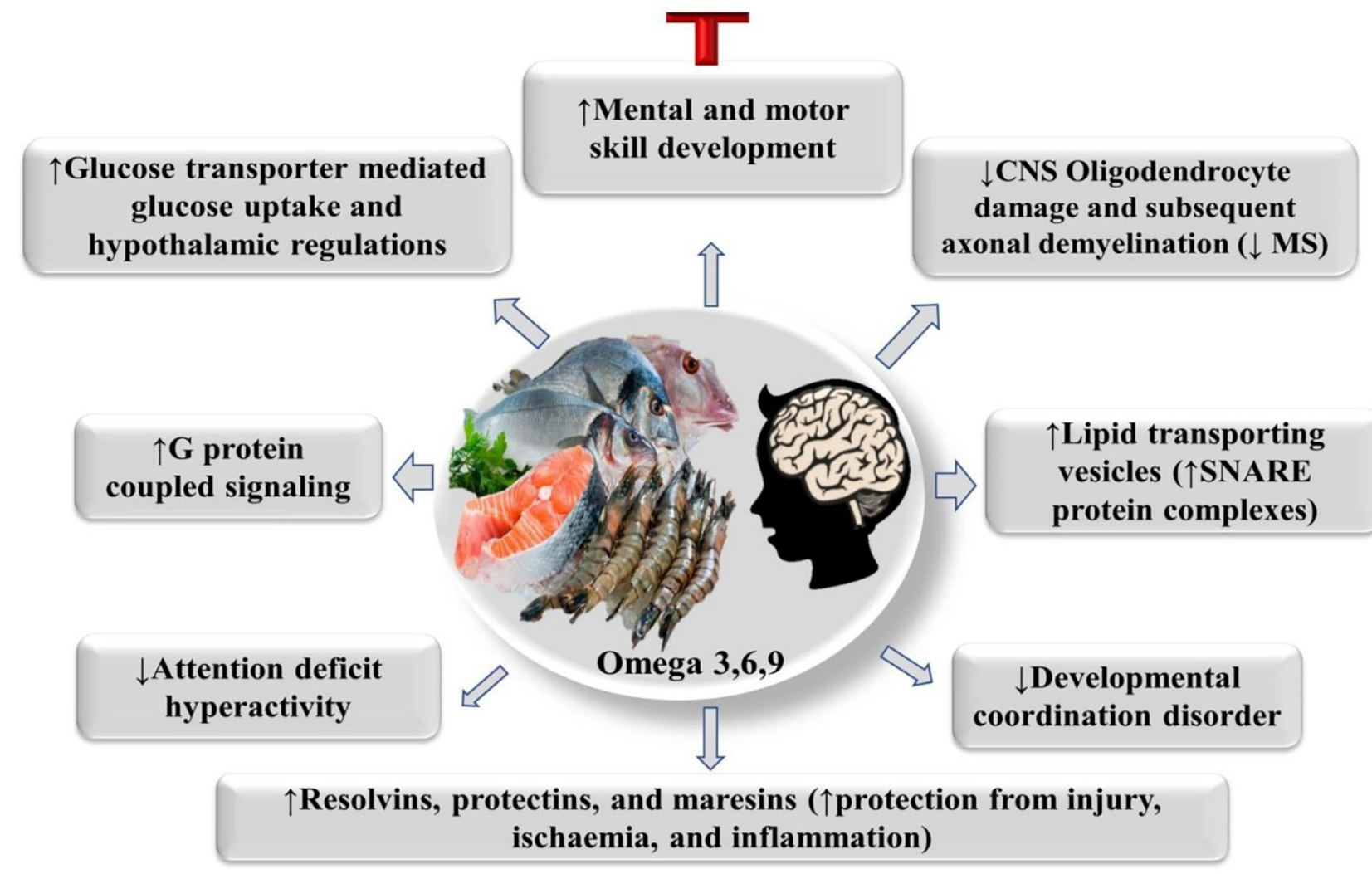

FIGURE 3 | PUFAs' physiological mode of action on brain health. CNS, Central nervous system, G protein-coupled signaling (leading to altered gene expression).

enhance their brain development and reading abilities (70, 75).

\section{Consumption of PUFAs by Children}

Omega-3 fatty acids are essential for children's health. Infants that were fed powdered formula with high grades of omega3 fatty acid had better eye-hand coordination, attention, and social skills, as well as higher Intelligence Quotient (IQ) test results (76-78). It was also discovered that consuming longchain polyunsaturated fatty acids (LCPUFAs) during pregnancy lengthened the pregnancy and lowered the frequency of premature deliveries $(79,80)$. According to Olsen et al. (81), children of moms who took fish oil during pregnancy had a lower risk of developing asthma in their teenage years. According to certain studies, powdered formula containing omega-3 helps preterm babies' growth and cognitive development $(82,83)$. The studies described above aren't conclusive; however they might be a cause to consume omega- 3 that contains DHA or EPA. As a result, DHA and EPA are included in many powdered formulas now on the market. Furthermore, breast milk is the best supply of omega-3 (84), however it is heavily influenced by the diet that mothers consume (84). Nevertheless, according to a recent meta-analysis on omega-3 fatty acids, there is insufficient data to establish if LCPUFAs consumption during pregnancy aids cognitive or visual development (85).

\section{Food Fish Quality and Safety}

The quality and safety of food products determines the protection of public health, social stability as well as the food and nutrition security $(2,86)$. Fish is vulnerable to contamination by pollutants such as heavy metals that threaten their safety for human consumption. Heavy metals are classified as elements having a high atomic weight and a density of at least five times greater compared to that of water and are present in nature from the earth's crust (87-90). Despite numerous heavy metal elements present in nature, mercury ( $\mathrm{Hg}$ ), arsenic (As), cadmium $(\mathrm{Cd})$, chromium $(\mathrm{Cr})$, and lead $(\mathrm{Pb})$ are considered the most toxic elements and threat to public health. The widespread contamination of heavy metals in aquatic environment results mainly from anthropogenic activities including agricultural, industrial (such as mining), medical, and domestic applications $(87,90)$. Fish accumulate heavy metals by uptake through the gills and the skin when in contact and can bioaccumulate and bio-magnify them to toxic levels for human consumption $(91,92)$. However, the risks associated with consuming fish depends on the levels of contamination. The Food and Agriculture Organization (FAO) has set limits within which fish contaminated with heavy metals is considered safe for consumption (Table 1). As indicated, some elements could be toxic even at low levels while others at higher levels. Invariably, the consumption of fish and fish products contaminated with 
TABLE 1 | Recommended values of some heavy metal elements by the food and agriculture organization FAO (106).

\begin{tabular}{lcc}
\hline Heavy metal & Value (wet weight) & Value (dry weight) \\
\hline $\mathrm{Cr}$ & $0.15-1.0 \mathrm{ppm}$ & $0.65-4.35 \mathrm{ppm}$ \\
$\mathrm{Zn}$ & $30.0 \mathrm{ppm}$ & $130.43 \mathrm{ppm}$ \\
$\mathrm{Mn}$ & $1.00 \mathrm{ppm}$ & $4.35 \mathrm{ppm}$ \\
$\mathrm{Fe}$ & $100.00 \mathrm{ppm}$ & $434.78 \mathrm{ppm}$ \\
$\mathrm{Co}$ & $0.04-0.26 \mathrm{ppm}$ & $0.17-1.13 \mathrm{ppm}$ \\
$\mathrm{Cu}$ & $30.00 \mathrm{ppm}$ & $130.43 \mathrm{ppm}$ \\
$\mathrm{Se}$ & $1.00 \mathrm{ppm}$ & $4.35 \mathrm{ppm}$ \\
$\mathrm{Hg}$ & $0.50 \mathrm{ppm}$ & $2.17 \mathrm{ppm}$ \\
$\mathrm{Pb}$ & $0.50 \mathrm{ppm}$ & $2.17 \mathrm{ppm}$ \\
$\mathrm{Ni}$ & $80.00 \mathrm{ppm}$ & $347.82 \mathrm{ppm}$ \\
$\mathrm{As}$ & $1.00 \mathrm{ppm}$ & $4.35 \mathrm{ppm}$ \\
\hline
\end{tabular}

heavy metals at levels beyond safe limits could have adverse effects in humans. However, children are more vulnerable due to their low body weight and behavior. For example, exposure to $\mathrm{Pb}$ in children could cause learning deficit, intelligence quotient (IQ) lowering, and severe damages in the brain and kidneys (93). Consuming excess Cd levels in fish products could result in kidney failure and bones softening, as well as prostate cancer in males $(94,95)$. Consumption of As in food products above safe level causes cardiovascular diseases, developmental anomalies, hearing defects, carcinoma, and hematologic disorders $(96,97)$. $\mathrm{Hg}$ is known to cause permanent damage to the central nervous system in children $(98,99)$. Effects such as heart function alteration, leukemia, kidney damage, neurocognitive defects and neuromotor disabilities have been reported in children exposed to $\mathrm{Hg}$ in sea food (100-102). Besides, Hg could affect children during any stage of development including maternal exposure particularly from methyl mercury (MeHg) species (87). Exposure to $\mathrm{Cr}$ could affect the functions of the heart, hematological parameters, kidneys, liver, and the central nervous system (103). Therefore, it is suggested that regular monitoring of heavy metals accumulation levels in aquatic environments and fish be conducted to safeguard public health $(104,105)$.

Fish, also being a perishable product, is vulnerable to fermentation and decomposition resulting in biogenic amines (BA) that threaten fish safety for consumption. BA refer to toxicants non-volatile amines resulting from amino acids decarboxylation (107). They are produced either by proteolytic activities of certain microorganisms or naturally during the metabolism of related precursor amino acids (108). However, in fish, histamine (HIS), cadaverine (CAD), and putrescine (PUT) are the only biogenic amines of concern when it comes to food safety and quality control (107). HIS is a monoamine produced from histidine precursor amino acid via a one-step decarboxylation reaction (108). CAD is a diamine produced from lysine and putrescine via a decarboxylation reaction (109). PUT is also a diamine but is produced either through a single-step decarboxylation from agmatine and ornithine, or indirectly after arginine hydrolysis (110). Although BA, at their physiological levels, play important roles in various cells process such as cell growth, gene expression, and tissue repair $(111,112)$, their ingestion at higher levels, although unlikely, could pose serious health hazards like symptoms of histamine poisoning including anaphylaxis, hypertension, nervous manifestation, and even death (113). Besides, Doeun et al. (114) reported that CAD and PUT could give way to gastric cancer during its conversion into carcinogenic $\mathrm{N}$-nitroso compounds by microorganisms present in the digestive tract. Furthermore, in Europe, consumption of fish containing elevated levels of BAs was associated with widespread cases of intoxication (European Food Safety Authority EFSA (115) Therefore, it is very important that fish products are screened for BAs before administered for consumption to safeguard public health. This can be done 2-fold: maintaining high level of hygiene during fish harvesting, storage, processing and distribution to consumers, and by controlling total mesophilic (TMC) and total psychrophilic (TPsC) bacterial counts in fish products. El-Ghareeb et al. (109) observed a positive correlation between total BAs and TMC, suggesting that microorganisms play a major role in contaminating fish products with BAs.

\section{Contextualizing Research on Children and Food Marketing}

To ensure the growth, health and development of children to their full potential, adequate nutrition during infancy and early childhood is essential. The most effective interventions to improve child health is through optimal infant and young child feeding practices (116). Poor diets will drive malnutrition in early childhood and millions of children are eating too little of what they need, and millions are eating too much of what they do not need which is the main risk factor for the global burden of diseases (117). According to Unicef (117) malnutrition, which is an umbrella term for both excess consumption of nutrients (overnutrition), inadequate consumption of nutrients (undernutrition) or micronutrient deficiency ("hidden hunger"), is primarily caused by a suboptimal diet. The burden of child undernutrition remains a global threat, with 21.3 percent of children under the age of 15 years stunted, 6.9 percent wasted and 340 million suffering from micronutrient deficiencies (3). It is reported by (118) and (119) that in addition to contributing to greater dietary diversity and boosting the micronutrient intake of women of reproductive age, the consumption of aquatic foods in the first 1,000 days of life from conception to a child's second birthday is associated with positive birth outcomes, a better nutrient composition of breastmilk, reduced stunting and a decline in the prevalence of severe acute malnutrition. It is also attested that eating fish early in life can promote positive behavioral and mental health outcomes and prevent certain allergies, such as asthma, eczema, and allergic rhinitis (41).

Aquatic foods, especially aquatic animals, have long been valued as a rich source of animal protein and thus, considered a key constituent of nutritious diets (120) but the policies on aquatic foods tend to focus primarily on production, economic efficiency, resource management, environment and climate issues whilst paying less attention to value chains and the contribution of aquatic foods to people's nutrition and health. Ahern et al. 
(121) recommended that aquatic foods are part of the solution to building resilient food systems and sustainable healthy diets for all, but for this to be fully achieved, they need to be available, accessible, affordable and desired. The nutritional value and health benefits of the fishes are unrecognized and undervalued. Despite a lot of benefits in the health of humans particularly the children, some people are still unaware of these benefits (122). The contribution of capture fisheries for instance to diet quality is poorly understood in most contexts, particularly where small-scale fisheries remain undocumented and overlooked in both fisheries and food system development $(123,124)$ hence limiting the nuanced assessment of fisheries contribution to diet quality of children under 12 years of age which is the critical age at which interventions have the greatest long-term effects for growth and health $(117,125)$. In contrast, Crona et al. (126) and HLPE (127) records that fish and other aquatic foods are gaining attention for their potential to efficiently provide two fundamental components of sustainable, nutritious food systems. Fish from inland fisheries are an important source of animal source foods (ASF) in monotonous diets for children in the subSaharan Africa and Asia (128), especially in land-locked African countries such as Malawi $(129,130)$ and Zambia (131). Therefore, there is a need to realize the importance of fish for human nutrition, in addition to its role in reducing poverty and hunger. This will ensure a greater impact by improving the nutritional status of children.

\section{CONCLUSION}

The nutritional benefits of fish consumption in children has been reviewed. Our findings show that fish is an important animal

\section{REFERENCES}

1. Allam BW, Khalil HS, Mansour AT, Srour TM, Omar EA, Nour AAM. Impact of substitution of fish meal by high protein distillers dried grains on growth performance, plasma protein and economic benefit of striped catfish (Pangasianodon hypophthalmus). Aquaculture. (2020) 517:734792. doi: 10.1016/j.aquaculture.2019.734792

2. Maulu S, Hasimuna OJ, Monde C, Mweemba M. An assessment of postharvest fish losses and preservation practices in Siavonga district, Southern Zambia. Fish Aquatic Sci. (2020) 23:1-9. doi: 10.1186/s41240-020-00170-x

3. FAO. The State of World Fisheries and Aquaculture 2020. Sustainability in Action. Rome: FAO (2020).

4. Willett W, Rockström J, Loken B, Springmann M, Lang T, Vermeulen $\mathrm{S}$, et al. Food in the anthropocene: the EAT-lancet commission on healthy diets from sustainable food systems. Lancet. (2019) 393:44792. doi: 10.1016/S0140-6736(18)31788-4

5. Mansour AT, Allam BW, Srour TM, Omar EA, Nour AM, Khalil HS. The feasibility of monoculture and polyculture of striped catfish and nile tilapia in different proportions and their effects on growth performance, productivity, and financial revenue. J Mar Sci Eng. (2021) 9:586. doi: 10.3390/jmse9060586

6. Ali A, El Sherif S, Abd Alla J, Maulu S, Tantawy AA, Soliman MFK, et al. Morphometric, histochemical, and ultrastructural analysis of the reproductive system and spermatogenic stages of male blue crab (Callinectessapidus Rathbun, 1896). J Mar Sci Eng. (2021) 9:1105. doi: 10.3390/jmse9101105

7. Khalil HS, Momoh T, Al-Kenawy D, Yossa R, Badreldin AM, Roem A, et al. Nitrogen retention, nutrient digestibility and growth efficiency of Nile tilapia protein source and its consumption is likely to increase over the coming years. This will be driven primarily by population increase and the demand for healthy and high-quality protein for human nutrition. The polyunsaturated fatty acids (PUFAs) that are highly present in fish play an important physiological role in the growth and development of fetuses, newborns, and children's brains. As a result, they should be provided in the diets of children for normal development. Besides, in situations including auto-immune illnesses diseases, PUFAs have been found to enhance blood flow, minimize chronic inflammation and decrease coronary artery disease.

\section{AUTHOR CONTRIBUTIONS}

SM and KN wrote the draft manuscript. MA-T reviewed the manuscript. HK designed the study and wrote and formulated the objectives, as well as reviewed the manuscript. All the authors read and approved the final manuscript.

\section{FUNDING}

This research was done jointly by Wageningen University, which provided support in the form of a postdoctoral fellowship, and the WorldFish Center's CGIAR Research Program (Trust Fund) on Fish Agri-Food Systems (FISH) [F11194].

\section{ACKNOWLEDGMENTS}

The authors are grateful for the support rendered by WorldFish Center, Abbassa, Egypt during this study.
(Oreochromis niloticus) fed dietary lysine and reared in fertilized ponds. Aquac Nutr. (2021) 00:1-13. doi: 10.1111/anu.13365

8. Maulu S, Hasimuna OJ, Haambiya LH, Monde C, Musuka CG, Makorwa $\mathrm{TH}$, et al. Climate change effects on aquaculture production: sustainability implications, mitigation, and adaptations. Front Sustain Food Syst. (2021). 5:609097. doi: 10.3389/fsufs.2021.609097

9. Schönfeldt HC, Hall NG. Dietary protein quality and malnutrition in Africa. B J Nutr. (2012) 108:S69-76. doi: 10.1017/S0007114512002553

10. Ruel M, Quisumbing A, Balagamwala M. Nutrition-sensitive agriculture: what have we learned so far? Glob Food Secur. (2018) 17:128-53. doi: 10.1016/j.gfs.2018.01.002

11. Müller O, Krawinkel M. Malnutrition and health in developing countries. CMAJ. (2005) 173:279-86. doi: 10.1503/cmaj.050342

12. Khalil HS, Mansour AT, Goda AMA, Omar EA. Effect of selenium yeast supplementation on growth performance, feed utilization, lipid profile, liver and intestine histological changes, and economic benefit in meagre, Argyrosomus regius, fingerlings. Aquaculture. (2019) 501:13543. doi: 10.1016/j.aquaculture.2018.11.018

13. Kord MI, Srour TM, Farag AA, Omar EA, Nour AM, Khalil HS. The immunostimulatory effects of commercial feed additives on growth performance, non-specific immune response, antioxidants assay, and intestinal morphometry of Nile tilapia, Oreochromis niloticus. Front Physiol. (2021) 12:111. doi: 10.3389/fphys.2021.627499

14. Hörnell A, Lagström H, Lande B, Thorsdottir I. Protein intake from 0 to 18 years of age and its relation to health: a systematic literature review for the 5th Nordic Nutrition Recommendations. Food Nutr Res. (2013) 57:21083. doi: 10.3402/fnr.v57i0.21083 
15. Springmann M, Clark M, Mason-D’Croz D, Wiebe K, Bodirsky BL, Lassaletta $\mathrm{L}$, et al. Options for keeping the food system within environmental limits. Nature. (2018) 562:519-25. doi: 10.1038/s41586-018-0594-0

16. Hasselberg AE, Aakre I, Scholtens J, Overå R, Kolding J, Bank MS, et al. Fish for food and nutrition security in Ghana: challenges and opportunities. Global Food Security. (2020) 26:100380. doi: 10.1016/j.gfs.2020.100380

17. OECD/FAO. OECD-FAO Agricultural Outlook 2018-2027. Paris; Rome: OECD Publishing /Food and Agriculture Organization of the United Nations (2018). doi: 10.1787/agr_outlook-2018-en

18. Ljusenius $\AA$, Lovatelli A, Qabeel B. The international year of artisanal fisheries and aquaculture is coming up in 2022. FAO Aquacult Newslett. (2020) 13-15. Available online at: https://www.fao.org/3/ca6973en/ CA6973EN.pdf

19. Tacon AG, Lemos D, Metian M. Fish for health: improved nutritional quality of cultured fish for human consumption. Rev Fish Sci Aquacult. (2020) 28:449-58. doi: 10.1080/23308249.2020.1762163

20. Khalil H, Mansour A, Goda A, El-Hammady A, Omar E. Effect of poly-unsaturated fatty acids fortification on growth performance, survival, fatty acid composition and antioxidant balance of meagre, Argyrosomus regius Larvae. J Aquac Res Dev. (2018) 9:2. doi: 10.4172/2155-9546. 1000529

21. Mansour AT, Goda AA, Omar EA, Khalil HS, Esteban MÁ. Dietary supplementation of organic selenium improves growth, survival, antioxidant and immune status of meagre, Argyrosomus regius, juveniles. Fish Shellfish Immun. (2017) 68:516-24. doi: 10.1016/j.fsi.2017.07.060

22. Thilsted SH, Thorne-Lyman A, Webb P, Bogard JR, Subasinghe R, Phillips MJ, et al. Sustaining healthy diets: The role of capture fisheries and aquaculture for improving nutrition in the post-2015 era. Food Policy. (2016) 61:126-31. doi: 10.1016/j.foodpol.2016.02.005

23. Roth DE, Abrams SA, Aloia J, Bergeron G, Bourassa MW, Brown KH, et al. Global prevalence and disease burden of vitamin D deficiency: a roadmap for action in low-and middle-income countries. Ann N Y Acad Sci. (2018) 1430:44. doi: 10.1111/nyas.13968

24. Kassebaum NJ, Jasrasaria R, Naghavi M, Wulf SK, Johns N, Lozano R, et al. A systematic analysis of global anemia burden from 1990 to 2010. Blood. (2014) 123:615-24. doi: 10.1182/blood-2013-06-508325

25. Imdad A, Jabeen A, Bhutta ZA. Role of calcium supplementation during pregnancy in reducing risk of developing gestational hypertensive disorders: a meta-analysis of studies from developing countries. BMC Public Health. (2011) 11:1-13. doi: 10.1186/1471-2458-11-S3-S1

26. Keen CL, Gershwin ME. Zinc deficiency and immune function. Annu Rev Nutr. (1990) 10:415-31. doi: 10.1146/annurev.nu.10.070190.002215

27. Mohanty B. Nutritional value of food fish. Conspectus Inland Fish Manag. (2015) 4:15-21.

28. Deaton A, Drèze J. Food and nutrition in India: facts and interpretations. Econ Polit Weekly. (2009) 2009:42-65. doi: 10.2139/ssrn.1135253

29. Tocher DR. Metabolism and functions of lipids and fatty acids in teleost fish. Rev Fish Sci. (2003) 11:107-84. doi: 10.1080/713610925

30. Singh H, Ye A, Horne D. Structuring food emulsions in the gastrointestinal tract to modify lipid digestion. Prog Lipid Res. (2009) 48:92-100. doi: 10.1016/j.plipres.2008.12.001

31. Ferjak E, Cavinder C, Sukumaran A, Burnett D, Lemley C, Dinh T. Fatty acid composition of mesenteric, cardiac, abdominal, intermuscular, and subcutaneous adipose tissues from horses of three body condition scores. Livest Sci. (2019) 223:116-23. doi: 10.1016/j.livsci.2019.02.010

32. Kanicky JR, Shah DO. Effect of degree, type, and position of unsaturation on the pKa of long-chain fatty acids. J Colloid Interface Sci. (2002) 256:2017. doi: 10.1006/jcis.2001.8009

33. Aldai N, de Renobales M, Barron LJR, Kramer JK. What are the trans fatty acids issues in foods after discontinuation of industrially produced trans fats? Ruminant products, vegetable oils, and synthetic supplements. Eur J Lipid Sci Technol. (2013) 115:1378-401. doi: 10.1002/ejlt.201300072

34. Boyland EJ, Halford JCG. Television advertising and branding. Effects on eating behaviour and food preferences in children. Appetite. (2013) 62:23641. doi: 10.1016/j.appet.2012.01.032

35. Finco AMdO, Mamani LDG, Carvalho JCd, de Melo Pereira GV, Thomaz-Soccol V, et al. Technological trends and market perspectives for production of microbial oils rich in omega-3. Crit
Rev Biotechnol. (2017) 37:656-71. doi: 10.1080/07388551.2016.12 13221

36. López-Pedrouso M, Lorenzo JM, Gullón B, Campagnol PCB, Franco D. Novel strategy for developing healthy meat products replacing saturated fat with oleogels. Curr Opin Food Sci. (2021) 40:40-5. doi: 10.1016/j.cofs.2020.06.003

37. Boateng L, Ansong R, Owusu W, Steiner-Asiedu M. Coconut oil and palm oil's role in nutrition, health and national development: A review. Ghana Med J. (2016) 50:189-96. doi: 10.4314/gmj.v50i3.11

38. DeMan JM, Finley JW, Hurst WJ, Lee CY. Principles of Food Chemistry. Berlin/Heidelberg: Springer (2018). doi: 10.1007/978-3-319-63607-8

39. Briggs MA, Petersen KS, Kris-Etherton PM. Saturated Fatty Acids and Cardiovascular Disease: Replacements for Saturated Fat to Reduce Cardiovascular Risk. Healthcare. (2017) 2017:29. doi: 10.3390/healthcare5020029

40. Sokoła-Wysoczańska E, Wysoczański T, Wagner J, Czyz K, Bodkowski R, Lochyński S, et al. Polyunsaturated fatty acids and their potential therapeutic role in cardiovascular system disorders-a review. Nutrients. (2018) 10:1561. doi: 10.3390/nu10101561

41. Bernstein AS, Oken E, de Ferranti S. Fish, shellfish, and children's health: an assessment of benefits, risks, and sustainability. Pediatrics. (2019) 143:999. doi: 10.1542/peds.2019-0999

42. Ranken MD. Food Industries Manual. Berlin/Heidelberg: Springer Science \& Business Media (2012).

43. Mason E, L'Hocine L, Achouri A, Karboune S. Hairless canaryseed: a novel cereal with health promoting potential. Nutrients. (2018) 10:1327. doi: 10.3390/nu10091327

44. Schuchardt JP, Huss M, Stauss-Grabo M, Hahn A. Significance of long-chain polyunsaturated fatty acids (PUFAs) for the development and behaviour of children. Eur J Pediatr. (2010) 169:149-64. doi: 10.1007/s00431-009-1035-8

45. SanGiovanni JP, Chew EY. The role of omega-3 long-chain polyunsaturated fatty acids in health and disease of the retina. Prog Retin Eye Res. (2005) 24:87-138. doi: 10.1016/j.preteyeres.2004.06.002

46. Simopoulos AP. An increase in the omega-6/omega-3 fatty acid ratio increases the risk for obesity. Nutrients. (2016) 8:128. doi: $10.3390 /$ nu 8030128

47. McGlory C, Calder PC, Nunes EA. The influence of omega-3 fatty acids on skeletal muscle protein turnover in health, disuse, and disease. Front Nutr. (2019) 6:144. doi: 10.3389/fnut.2019.00144

48. Saini RK, Keum Y. Omega-3 and omega-6 polyunsaturated fatty acids: dietary sources, metabolism, and significance-a review. Life Sci. (2018) 203:255-67. doi: 10.1016/j.lfs.2018.04.049

49. Mittal A, Sara U, Ali AH, Aqil M. Status of fatty acids as skin penetration enhancers-a review. Curr Drug Deliv. (2009) 6:274-9. doi: 10.2174/156720109788680877

50. Ishak WMW, Katas H, Yuen NP, Abdullah MA, Zulfakar MH. Topical application of omega-3-, omega-6-, and omega-9-rich oil emulsions for cutaneous wound healing in rats. Drug Deliv Transl Res. (2019) 9:41833. doi: $10.1007 / \mathrm{s} 13346-018-0522-8$

51. USDA. National Nutrient Database for Standard Reference, Release 28. Nutrients: Vitamin C, Total Ascorbic Acid. Washington, DC (2015).

52. Asif M. Health effects of omega-3, 6, 9 fatty acids: Perilla frutescens is a good example of plant oils. Orient Pharm Exp Med. (2011) 11:519. doi: 10.1007/s13596-011-0002-x

53. Ruiz Ruiz JC, Ortiz Vazquez EDL, Segura Campos MR. Encapsulation of vegetable oils as source of omega-3 fatty acids for enriched functional foods. Crit Rev Food Sci Nutr. (2017) 57:1423-34. doi: 10.1080/10408398.2014.1002906

54. Venegas-Calerón M, Sayanova O, Napier JA. An alternative to fish oils: metabolic engineering of oil-seed crops to produce omega-3 long chain polyunsaturated fatty acids. Prog Lipid Res. (2010) 49:10819. doi: 10.1016/j.plipres.2009.10.001

55. Dyall SC. Long-chain omega-3 fatty acids and the brain: a review of the independent and shared effects of EPA, DPA and DHA. Front Aging Neurosci. (2015) 7:52. doi: 10.3389/fnagi.2015.00052

56. Covington M. Omega-3 fatty acids. Am Fam Physician. (2004) 70:133-40. Available online at: https://www.aafp.org/afp/2004/0701/afp20040701p133. pdf 
57. Eddey S. Omega-6 and 9 fatty acids. J Complement Med. (2008) 7:34-9.

58. Simopoulos AP. The omega-6/omega-3 fatty acid ratio, genetic variation, and cardiovascular disease. Asia Pac J Clin Nutr. (2008) 17 Suppl 1:131-4.

59. Medeiros-de-Moraes IM, Gonçalves-de-Albuquerque CF, Kurz AR, Oliveira FMJ, Abreu VHP, Torres RC, et al. Omega- 9 oleic acid, the main compound of olive oil, mitigates inflammation during experimental sepsis. Oxid Med Cell Longevity. (2018) 2018:6053492. doi: 10.1155/2018/6053492

60. Syed A. Future of Omega-9 oils. Canola and Rapessed Production, Processing, Food Quality, and Nutrition. Boca Raton, FL: CRC Press (2012). p. 79-100.

61. Williams CM. Dietary fatty acids and human health. Annales de Zootechnie. (2000) 2000:165-80. doi: 10.1051/animres:2000116

62. Tocher DR, Betancor MB, Sprague M, Olsen RE, Napier JA. Omega-3 longchain polyunsaturated fatty acids, EPA and DHA: bridging the gap between supply and demand. Nutrients. (2019) 11:89. doi: 10.3390/nu11010089

63. Zárate R, el Jaber-Vazdekis N, Tejera N, Pérez JA, Rodríguez C. Significance of long chain polyunsaturated fatty acids in human health. Clin Transl Med. (2017) 6:1-19. doi: 10.1186/s40169-017-0153-6

64. Tani S, Nagao K, Matsumoto M, Hirayama A. Highly purified eicosapentaenoic acid may increase low-density lipoprotein particle size by improving triglyceride metabolism in patients with hypertriglyceridemia. Circul J. (2013) 77:2349-57. doi: 10.1253/circj.CJ-12-1401

65. Fitria PD, Amin M, Lokapirnasari WP, Lamid M. Supplementation of fermented coffee-peel flour to increase high-density lipoprotein (HDL) cholesterol, docosahexaenoic acids (DHA) and eicosapentaenoic acids (EPA) deposition in tilapia fillet. Biocatal Agric Biotechnol. (2020) 24:101502. doi: 10.1016/j.bcab.2020.101502

66. Cornelius C, Crupi R, Calabrese V, Graziano A, Milone P, Pennisi G, et al. Traumatic brain injury: oxidative stress and neuroprotection. Antioxid Redox Signal. (2013) 19:836-53. doi: 10.1089/ars.2012.4981

67. Sibille E, Berdeaux O, Martine L, Bron AM, Creuzot-Garcher CP, He Z, et al. Ganglioside profiling of the human retina: Comparison with other ocular structures, brain and plasma reveals tissue specificities. PLoS ONE. (2016) 11:e0168794. doi: 10.1371/journal.pone.0168794

68. Muscaritoli M. The impact of nutrients on mental health and well-being: insights from the literature. Front Nutr. (2021) 8:97. doi: $10.3389 /$ fnut.2021.656290

69. Lee J. Polyunsaturated fatty acids in children. Pediatr Gastroenterol Hepatol Nutr. (2013) 16:153-61. doi: 10.5223/pghn.2013.16.3.153

70. Innis SM. Dietary (n-3) fatty acids and brain development. J Nutr. (2007) 137:855-9. doi: 10.1093/jn/137.4.855

71. Kitajka K, Puskás LG, Zvara Á, Hackler L, Barceló-Coblijn G, Yeo YK, et al. The role of $n-3$ polyunsaturated fatty acids in brain: modulation of rat brain gene expression by dietary n-3 fatty acids. Proc Nat Acad Sci USA. (2002) 99:2619-24. doi: 10.1073/pnas.042698699

72. Stillwell W, Wassall SR. Docosahexaenoic acid: membrane properties of a unique fatty acid. Chem Phys Lipids. (2003) 126:1-27. doi: 10.1016/S0009-3084(03)00101-4

73. Salem N, Litman B, Kim H, Gawrisch K. Mechanisms of action of docosahexaenoic acid in the nervous system. Lipids. (2001) 36:94559. doi: 10.1007/s11745-001-0805-6

74. Siegert E, Paul F, Rothe M, Weylandt KH. The effect of omega-3 fatty acids on central nervous system remyelination in fat-1 mice. BMC Neurosci. (2017) 18:1-9. doi: 10.1186/s12868-016-0312-5

75. Johnson M, Fransson G, Östlund S, Areskoug B, Gillberg C. Omega 3/6 fatty acids for reading in children: a randomized, double-blind, placebocontrolled trial in 9-year-old mainstream schoolchildren in Sweden. J Child Psychol Psychiatry. (2017) 58:83-93. doi: 10.1111/jcpp.12614

76. Uauy R, Dangour AD. Fat and fatty acid requirements and recommendations for infants of 0-2 years and children of 2-18 years. Ann Nutr Metab. (2009) 55:76-96. doi: 10.1159/000228997

77. Campoy C, Escolano-Margarit MV, Ramos R, Parrilla-Roure M, Csábi G, Beyer J, et al. Effects of prenatal fish-oil and 5-methyltetrahydrofolate supplementation on cognitive development of children at $6.5 \mathrm{y}$ of age. Am J Clin Nutr. (2011) 94:1880S-8S. doi: 10.3945/ajcn.110.001107

78. Pusceddu MM, Kelly P, Stanton C, Cryan JF, Dinan TG. N-3 polyunsaturated fatty acids through the lifespan: implication for psychopathology. Int $J$ Neuropsychopharmacol. (2016) 19:pyw078. doi: 10.1093/ijnp/pyw078
79. Chavan-Gautam P, Rani A, Freeman DJ. Distribution of fatty acids and lipids during pregnancy. Adv Clin Chem. (2018) 84:209-39. doi: 10.1016/bs.acc.2017.12.006

80. Muhlhausler BS, Collins CT, Gould JF, Best KP, Leghi GE. Polyunsaturated fatty acids: metabolism and nutritional requirements in pregnancy and infancy. Polyunsatur Fatty Acid Metabol. (2018) 2018:111-34. doi: 10.1016/B978-0-12-811230-4.00007-7

81. Olsen SF, Østerdal ML, Salvig JD, Mortensen LM, Rytter D, Secher NJ, et al. Fish oil intake compared with olive oil intake in late pregnancy and asthma in the offspring: $16 \mathrm{y}$ of registry-based follow-up from a randomized controlled trial. Am J Clin Nutr. (2008) 88:167-75. doi: 10.1093/ajcn/88.1.167

82. Juber BA, Jackson KH, Johnson KB, Harris WS, Baack ML. Breast milk DHA levels may increase after informing women: a communitybased cohort study from South Dakota USA. Int Breastfeed J. (2017) 12:7. doi: 10.1186/s13006-016-0099-0

83. Cunnane SC, Crawford MLA. Energetic and nutritional constraints on infant brain development: implications for brain expansion during human evolution. J Hum Evol. (2014) 77:88-98. doi: 10.1016/j.jhevol.2014.05.001

84. Mazurier E, Rigourd V, Perez P, Buffin R, Couedelo L, Vaysse $\mathrm{C}$, et al. Effects of maternal supplementation with omega-3 precursors on human milk composition. J Hum Lactation. (2017) 33:319-28. doi: 10.1177/0890334417691946

85. Fereidoon S, Priyatharini A. Omega-3 polyunsaturated fatty acids and their health benefits. Annu Rev Food Sci Technol. (2018) 9:34581. doi: 10.1146/annurev-food-111317-095850

86. Kord MI, Maulu S, Srour TM, Omar EA, Farag AA, Nour AAM, et al. Impacts of water additives on water quality, production efficiency, intestinal morphology, gut microbiota, and immunological responses of Nile tilapia fingerlings under a zero-water-exchange system. Aquaculture. (2021) 547:737503. doi: 10.1016/j.aquaculture.2021.737503

87. Tchounwou PB, Yedjou CG, Patlolla AK, Sutton DJ. Heavy metal toxicity and the environment. In: A Luch, editor, Molecular, Clinical and Environmental Toxicology, vol. 101. Berlin: Springer (2012). p. 13364. doi: 10.1007/978-3-7643-8340-4_6

88. Elnabris KJ, Muzyed SK, El-Ashgar NM. Heavy metal concentrations in some commercially important fishes and their contribution to heavy metals exposure in Palestinian people of Gaza Strip (Palestine). J Assoc Arab Univ Basic Appl Sci. (2013) 13:44-51. doi: 10.1016/j.jaubas.2012.06.001

89. Saha N, Mollah MZI, Alam MF, Rahman MS. Seasonal investigation of heavy metals in marine fishes captured from the Bay of Bengal and the implications for human health risk assessment. Food Control. (2016) 70:1108. doi: 10.1016/j.foodcont.2016.05.040

90. Hasimuna OJ, Chibesa M, Ellender BR, Maulu S. Variability of selected heavy metals in surface sediments and ecological risks in the solwezi and kifubwa rivers, northwestern province, Zambia. Scientific African. (2021) 2021:e00822. doi: 10.1016/j.sciaf.2021.e00822

91. Gbogbo F, Arthur-Yartel A, Bondzie JA, Dorleku W, Dadzie S, KwansaBentum B, et al. Risk of heavy metal ingestion from the consumption of two commercially valuable species of fish from the fresh and coastal waters of Ghana. PLoS ONE. (2018) 13:e0194682. doi: 10.1371/journal.pone.0194682

92. Adegbola IP, Aborisade BA, Adetutu A. Health risk assessment and heavy metal accumulation in fish species (Clarias gariepinus and Sarotherodon melanotheron) from industrially polluted Ogun and Eleyele Rivers, Nigeria. Toxicol Rep. (2021) 8:1445-60. doi: 10.1016/j.toxrep.2021.07.007

93. Rubin R, Strayer DS, Rubin E. Rubin's Pathology: Clinicopathologic Foundations of Medicine. Philadelphia, PA: Lippincott Williams \& Wilkins (2008).

94. Vannoort RW, Thomson BM. 04 New Zealand Total Diet Survey: Agricultural Compound Residue, Selected Contaminants and Nutrients. Wellington: New Zealand Food Safety Authority (2003). p. 144.

95. Gray MA, Harrins A, Centeno JA. The role of cadmium, zinc, and selenium in prostate disease. Metal Contaminants New Zealand. (2005) 20:393-414.

96. Tchounwou PB, Centeno JA, Patlolla AK. Arsenic toxicity, mutagenesis, and carcinogenesis-a health risk assessment and management approach. Mol Cell Biochem. (2004) 255:47-55. doi: 10.1023/B:MCBI.0000007260.32981.b9

97. Centeno JA, Tchounwou PB, Patlolla AK, Mullick FG, Murakata L, Meza E, et al. Environmental pathology and health effects of arsenic poisoning. 
Manag Arsenic Environ. (2006) 2006:311-27. Available online at: https:// www.cabdirect.org/cabdirect/abstract/20063091827

98. Murata K, Weihe P, Budtz-Jørgensen E, Jørgensen PJ, Grandjean P. Delayed brainstem auditory evoked potential latencies in 14-yearold children exposed to methylmercury. J Pediatr. (2004) 144:17783. doi: 10.1016/j.jpeds.2003.10.059

99. Grandjean P. Methylmercury toxicity and functional programming. Reprod Toxicol. (2007) 23:414-20. doi: 10.1016/j.reprotox.2007.03.002

100. Grandjean P, Murata K, Budtz-Jørgensen E, Weihe P. Cardiac autonomic activity in methylmercury neurotoxicity: 14-year follow-up of a Faroese birth cohort. J Pediatr. (2004) 144:169-76. doi: 10.1016/j.jpeds.2003.10.058

101. Yorifuji T, Tsuda T, Kawakami N. Age standardized cancer mortality ratios in areas heavily exposed to methyl mercury. Int Arch Occup Environ Health. (2007) 80:679-88. doi: 10.1007/s00420-007-0179-y

102. Bose-O’Reilly S, McCarty KM, Steckling N, Lettmeier B. Mercury exposure and children's health. Curr Probl Pediatric Adolesc Health Care. (2010) 40:186-215. doi: 10.1016/j.cppeds.2010.07.002

103. Shekhawat K, Chatterjee S, Joshi B. Chromium toxicity and its health hazards. Int J Adv Res. (2015) 3:167-72.

104. Järup L. Hazards of heavy metal contamination. Br Med Bull. (2003) 68:16782. doi: $10.1093 / \mathrm{bmb} / \operatorname{ldg} 032$

105. Miri M, Akbari E, Amrane A, Jafari SJ, Eslami H, Hoseinzadeh E, et al. Health risk assessment of heavy metal intake due to fish consumption in the Sistan region, Iran. Environ Monit Assess. (2017) 189:110. doi: 10.1007/s10661-017-6286-7

106. FAO. Compilation of Legal Limits for Hazardous Substances in Fish and Fishery Products. Rome: Fisheries Circular (FAO). (1983). p. 764.

107. Bulushi IAL, Poole S, Deeth HC, Dykes GA. Biogenic amines in fish: roles in intoxication, spoilage, and nitrosamine formation-a review. Crit Rev Food Sci Nutr. (2009) 49:369-77. doi: 10.1080/10408390802067514

108. Marcobal A, De Las Rivas B, Landete JM, Tabera L, Muñoz R. Tyramine and phenylethylamine biosynthesis by food bacteria. Crit Rev Food Sci Nutr. (2012) 52:448-67. doi: 10.1080/10408398.2010.500545

109. El-Ghareeb WR, Elhelaly AE, Abdallah KME, El-Sherbiny HMM, Darwish WS. Formation of biogenic amines in fish: dietary intakes and health risk assessment. Food Sci Nutr. (2021) 9:3123-9. doi: 10.1002/fsn3.2271

110. Wunderlichová L, Bunková L, Koutný M, Jančová P, Bunka F. Formation, degradation, and detoxification of putrescine by foodborne bacteria: a review. Comprehens Rev Food Sci Food Saf. (2014) 13:1012-30. doi: 10.1111/1541-4337.12099

111. Galgano F, Caruso M, Condelli N, Favati F. Focused review: agmatine in fermented foods. Front Microbiol. (2012) 3:199. doi: 10.3389/fmicb.2012.00199

112. Ma J, Raslan AA, Elbadry S, El-Ghareeb WR, Mulla ZS, Bin-Jumah M, et al. Levels of biogenic amines in cheese: Correlation to microbial status, dietary intakes, and their health risk assessment. Environmental Science and Pollution Research. (2020) 27:44452-9. doi: 10.1007/s11356-020-10401-2

113. Medina MÁ, Urdiales JL, Rodríguez-Caso C, Ramírez FJ, Sánchez-Jiménez F. Biogenic amines and polyamines: similar biochemistry for different physiological missions and biomedical applications. Crit Rev Biochem Mol Biol. (2003) 38:23-59. doi: 10.1080/713609209

114. Doeun D, Davaatseren M, Chung M. Biogenic amines in foods. Food Sci Biotechnol. (2017) 26:1463-74. doi: 10.1007/s10068-017-0239-3

115. EFSA (111). EFSA Panel on Biological Hazards, 2011. Scientific opinion on risk based control of biogenic amine formation in fermented foods. Efsa J. 9:2393. doi: 10.2903/j.efsa.2011.2393

116. WHO. Infant and Young Child Feeding: Model Chapter for Textbooks for Medical Students and Allied Health Professionals. Geneva: World Health Organization (2009). Available online at: https://apps.who.int/iris/handle/ $10665 / 44117$

117. Unicef. The State of the World's Children 2019: Children, Food and Nutrition: Growing Well in a Changing World. New York, NY: Unicef (2019).

118. Yilma S, Busse H, Desta DT, Alemayehu FR. Fish Consumption, Dietary Diversity and Nutritional Status of Reproductive Age Women of Fishing and
Non-Fishing Households in Hawassa, Ethiopia: Comparative Cross Sectional Study (2020).

119. Fiorella KJ, Milner EM, Bukusi E, Fernald LC. Quantity and species of fish consumed shape breast-milk fatty acid concentrations around Lake Victoria, Kenya. Public Health Nutr. (2018) 21:777-84. doi: 10.1017/S1368980017003147

120. Burlingame B, Dernini S. Sustainable Diets and Biodiversity Directions and Solutions for Policy, Research and Action. Rome: FAO Headquarters (2012).

121. Ahern M, Thilsted S, Oenema S, Kühnhold H. The Role of Aquatic Foods in Sustainable Healthy Diets. UN Nutrition Discussion Paper. Rome: UN Nutition (2021).

122. Balami S, Sharma A, Karn R. Significance of nutritional value of fish for human health. Malaysian J Halal Res J. (2019) 2:32-4. doi: 10.2478/mjhr-2019-0012

123. Lynch AJ, Cooke SJ, Deines AM, Bower SD, Bunnell DB, Cowx IG, et al. The social, economic, and environmental importance of inland fish and fisheries. Environ Rev. (2016) 24:115-21. doi: 10.1139/er-2015-0064

124. Funge-Smith S, Bennett A. A fresh look at inland fisheries and their role in food security and livelihoods. Fish Fisheries. (2019) 20:117695. doi: 10.1111/faf.12403

125. Dewey KG. The challenge of meeting nutrient needs of infants and young children during the period of complementary feeding: an evolutionary perspective. J Nutr. (2013) 143:2050-4. doi: 10.3945/jn.113.182527

126. Crona BI, Basurto X, Squires D, Gelcich S, Daw TM, Khan A, et al. Towards a typology of interactions between small-scale fisheries and global seafood trade. Marine Policy. (2016) 65:1-10. doi: 10.1016/j.marpol.2015.11.016

127. HLPE. Aquaculture for Food Security and Nutrition. A report by the High Level Panel of Experts on Food Security and Nutrition of the Committee on World Food Security. Rome: HLPE (2014).

128. Choudhury S, Headey DD, Masters WA. First foods: diet quality among infants aged 6-23 months in 42 countries. Food Policy. (2019) 88:101762. doi: 10.1016/j.foodpol.2019.101762

129. Kaimila Y, Divala O, Agapova SE, Stephenson KB, Thakwalakwa C, Trehan $\mathrm{I}$, et al. Consumption of animal-source protein is associated with improved height-for-age $\mathrm{z}$ scores in rural Malawian children aged 12-36 months. Nutrients. (2019) 11:480. doi: 10.3390/nu11020480

130. Stewart CP, Caswell B, Iannotti L, Lutter C, Arnold CD, Chipatala R, et al. The effect of eggs on early child growth in rural Malawi: the Mazira Project randomized controlled trial. Am J Clin Nutr. (2019) 110:102633. doi: 10.1093/ajcn/nqz163

131. Marinda PA, Genschick S, Khayeka-Wandabwa C, Kiwanuka-Lubinda R, Thilsted SH. Dietary diversity determinants and contribution of fish to maternal and under-five nutritional status in Zambia. PLoS ONE. (2018) 13:e0204009. doi: 10.1371/journal.pone.02 04009

Conflict of Interest: The authors declare that the research was conducted in the absence of any commercial or financial relationships that could be construed as a potential conflict of interest.

Publisher's Note: All claims expressed in this article are solely those of the authors and do not necessarily represent those of their affiliated organizations, or those of the publisher, the editors and the reviewers. Any product that may be evaluated in this article, or claim that may be made by its manufacturer, is not guaranteed or endorsed by the publisher.

Copyright (C) 2021 Maulu, Nawanzi, Abdel-Tawwab and Khalil. This is an openaccess article distributed under the terms of the Creative Commons Attribution License (CC BY). The use, distribution or reproduction in other forums is permitted, provided the original author(s) and the copyright owner(s) are credited and that the original publication in this journal is cited, in accordance with accepted academic practice. No use, distribution or reproduction is permitted which does not comply with these terms. 